https://nv.nltu.edu.ua

https://doi.org/10.15421/40290203

$@ \square$ Correspondence author

Article received 12.03.2019 p.

Article accepted 28.03.2019 p.

M. V. Matusiak

удк 630*228(477.43/.44)

mikhailo1988@gmail.com

М. В. Матусяк

Вінницький національний аграрний університет, м. Вінниия, Украӥна

\title{
ВИКОРИСТАННЯ ТИПОЛОГІЧНОГО ПОТЕНЦІАЛУ ОСНОВНИХ ЛІСОТВІРНИХ ПОРІД В УМОВАХ ПОДІЛЛЯ
}

\begin{abstract}
Наведено результати дослідження лісотипологічного потенціалу основних лісотвірних порід насіннєвого та вегетативного походження. Виявлено низку відмінностей між темпами росту та продуктивністю насіннєвих і порослевих насаджень основних лісотвірних порід Поділля. З'ясовано, що різниця між запасами дуба звичайного вегетативного походження модальних та оптимальних деревостанів чітко простежується вже у 2 класі віку. Найбільша різниця в запасі проявляється у віці 100 років і становить майже 50 \%. Встановлено, що у дубових деревостанах насінного походження різниця між оптимальними та модальними деревостанами найбільше проявляється у 110-річному віці і продовжує зростати до 140 років. Також вивчено лісотипологічний потенціал насіннєвих ясеневих деревостанів. У ході проведених досліджень з'ясовано, що значне зниження запасу модальних ясеневих деревостанів спостерігається у 80-100-річному віці. Підраховано, що у 140-річному віці запас деревини в модальних деревостанах виявився на $170 \mathrm{~m}^{3} \cdot \mathrm{ra}^{-1}$ нижчим, ніж в оптимальних. У букових деревостанах 3 віком відмінності за запасом між оптимальними і модальними показниками значно посилюються і у 80-річному віці різниця становить $100 \mathrm{~m}^{3} \cdot \mathrm{ra}^{-1}$. За зведеними даними, середній оптимальний запас для основних деревостанів Поділля становить близько $340 \mathrm{~m}^{3} \cdot \mathrm{ra}^{-1}$. Величина фактичного запасу становить $237 \mathrm{~m}^{3} /$ га. Відхилення середніх запасів деревостанів становить $104 \mathrm{~m}^{3} \cdot г^{-1}(32 \%)$. Найбільші втрати від недовикористання лісорослинного потенціалу та запровадження неефективних лісогосподарських методів характерне для дубових $(50,1 \%)$ та букових $(30,3 \%)$ деревостанів. Згідно 3 отриманими даними встановлено, що основна частка втрат продуктивності деревостанів зумовлена недовикористанням лісорослинного потенціалу (32,04 \%). Втрата від інших факторів $є$ незначною і не перевищує $1 \%$ від загального запасу деревини.
\end{abstract}

Ключові слова: лісорослинний потенціал; запас; продуктивність; вік; рубки головного користування; лісотвірні породи.

Вступ. Високі темпи денатуралізації природного середовища, що тривають упродовж останніх двох століть, істотно змінили природні риси середовища, призвели до збіднення біорозмаїття, зниження генетичного, екологічного та продукційного потенціалу. Це особливо стосується лісових екосистем, що зазнали істотних господарських перетворень. Швидкі темпи індустріалізації та урбанізації, які охопили здавна Україну, призвели до значних антропогенних порушень лісів, їх просторового та вікового розподілу. 3 іншого боку, ліс увесь час був об'єктом комплексного і не завжди раціонального використання людиною. Внаслідок цього він зазнав значних негативних змін, що позначилось не тільки на його біологічній продуктивності, але й на багатогранних соціальних і захисних функціях, потреба у яких залишається постійно високою (Holubets, 2003). Незважаючи на економічну стагнацію та сьогоднішню невизначеність основних принципів ринкового господарювання, потреба у високоцінних сортиментах для господарських і промислових цілей є досить відчутною і гострою. Багаторічний досвід переконливо засвідчує, що традиційні методи господарювання 3 акцентом на суцільні рубки та наступне паросткове поновлення чи створення лісових культур не змогли реалізувати ідею розширеного відтворення високопродуктивних і стійких лісостанів України (Maurer, Hordiienko \& Brovko, 2008).

Аналіз останніх досліджень і публікацій. У наукових працях більшості вчених наголошено про можливість використання природного лісорослинного потенціалу основних лісотвірних порід та можливість його застосування для потреб лісовідновлення (Didenko, 2008; Levchenko, 2006; Bondar, 2003; Bondar \& Hordiienko, 2006). В умовах Поділля ефективність використання лісорослинного потенціалу для основних лісотвірних порід регіону досліджували такі науковці, як А. О. Бондар, Л. І. Копій, О. Г. Василевський, І. С. Нейко.

Мета дослідження - оцінити сучасний стан та використання лісорослинного потенціалу основних лісотвірних порід насіннєвого та вегетативного походження, їх структурно-функціональні та еколого-ценотичні особливості в умовах регульованого господарського використання, визначити шляхи їх ефективного та повноцінного відтворення.

Результати дослідження та їх обговорення. Аналіз ефективності використання лісорослинного потенціалу проведено для основних лісотвірних деревних видів окремих регіонів Поділля. Найпоширенішим деревним видом є дуб звичайний. На Поділлі дубові деревостани мають насінне і порослеве походження. Вони відрізняються між собою за інтенсивністю росту і продуктив-

Інформація про авторів:

Матусяк Михайло Васильович, канд. с.-г. наук, ст. викладач, кафедра садово-паркового господарства, садівництва та виноградарства. Email: mikhailo1988@gmail.com; https://orcid.org/0000-0001-8099-7290

Цитування за ДСту: Матусяк М. В. Використання типологічного потенціалу основних лісотвірних порід в умовах Поділля. Науковий вісник НЛТУ України. 2019, т. 29, № 2. С. 20-22.

Citation APA: Matusiak, M. V. (2019). The use of typological potential of major scales in Podillya region. Scientific Bulletin of UNFU, 29(2), 20-22. https://doi.org/10.15421/40290203 
ністю. Тому визначення типологічного потенціалу для деревостанів дуба насінного і природного походження проводили окремо.

Динаміку запасів оптимальних і модальних за продуктивністю дубових деревостанів порослевого походження (II бонітет) наведено на рис. 1. 3 рисунку видно, що відмінності у запасах між модальними і оптимальними деревостанами спостерігаються уже у віці 10 років. Починаючи із 2 класу віку різниця між оптимальними за запасом та модальними деревостанами значно зростає. Лінії тренду мають тенденцію до значного розходження до 100-річного віку. Порівняно із деревостанами насінного походження різниця між оптимальними i модальними насадженнями $\epsilon$ значно більшою, що свідчить про вкрай негативні наслідки господарювання у них. Зокрема, у віці понад 100 років розходження у запасах становить понад $50 \%$.

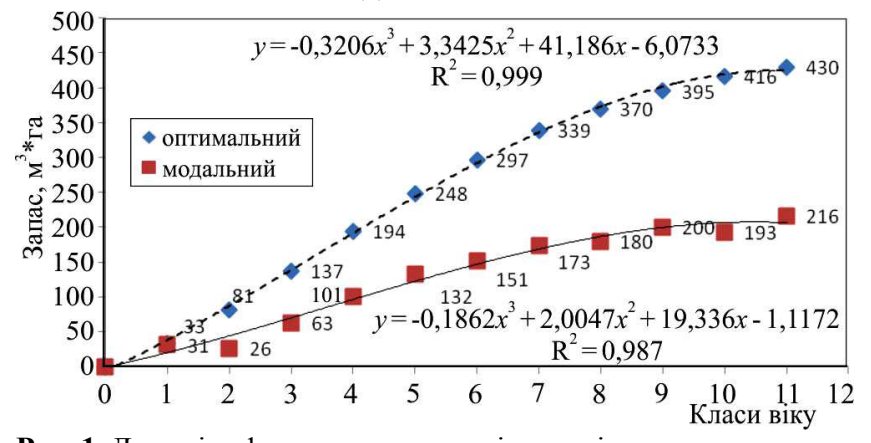

Рис. 1. Динаміка формування середніх запасів оптимальних за продуктивністю та модальних (фактичних) деревостанів дуба звичайного порослевого походження (II бонітет)

Динаміку запасів оптимальних і модальних за продуктивністю дубових деревостанів насінного походження I бонітету наведено на рис. 2. 3 рисунку видно, що розходження між запасами оптимальних і модальних дубових деревостанів насінного походження спостерігаються уже у 2 класі віку. Встановлено, що лінія тренду оптимальних за продуктивністю деревостанів має стійку тенденцію до зростання. Водночас значне зниження запасів спостерігається 3 110-річного віку. Саме в 11 класі віку виявлено найінтенсивніше розходження запасів оптимальних і модальних деревостанів. Ця різниця інтенсивно зростає до 140-річного віку.

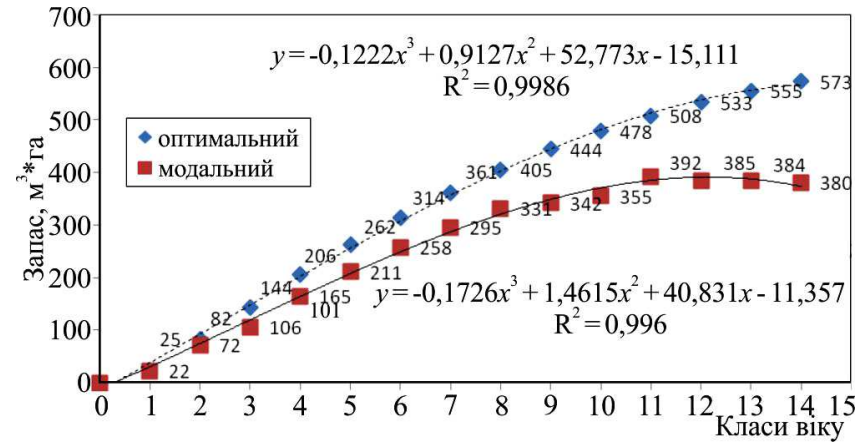

Рис. 2. Динаміка формування середніх запасів оптимальних за продуктивністю та модальних (фактичних) деревостанів дуба звичайного насінного походження (I бонітет)

На рис. 3 показано динаміку формування середніх запасів оптимальних за продуктивністю і модальних деревостанів ясена звичайного. 3 рисунку видно, що в молодняків і навіть середньовікових модальних і оптимальних ясеневих деревостанів формування запасів деревини $є$ подібним. Відмінності між ними $є$ незначними. Значне зниження запасу модальних ясеневих дере- востанів спостерігається 3 80-100-річного віку і в подальшому зберігає тенденцію до посилення цих відмінностей. У 140-річному віці запас деревини в модальних деревостанів виявився на $170 \mathrm{~m}^{3} \cdot \mathrm{ra}^{-1}$ нижчим, ніж в оптимальних. Очевидно це пов'язано зі значним вирубуванням деревини в процесі проведення санітарних рубок.

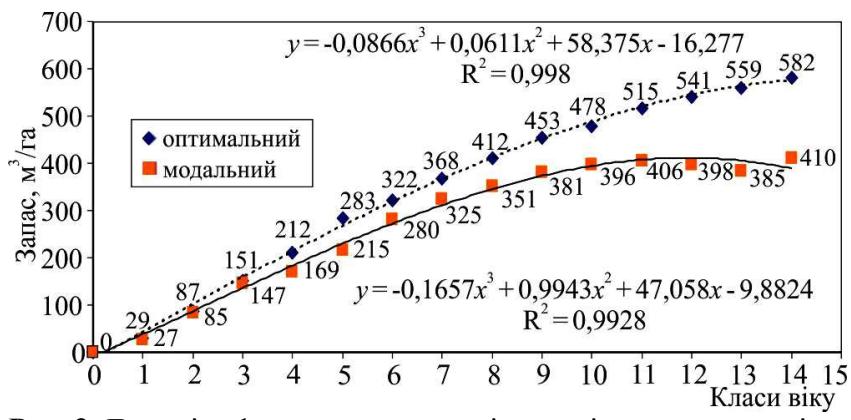

Рис. 3. Динаміка формування середніх запасів оптимальних і модальних (фактичних) деревостанів ясена звичайного насінного походження (I бонітет)

Не повною мірою використання типологічного потенціалу спостерігається також і в букових деревостанах (рис. 4). 3 рисунку видно, що різниця між оптимальними та модальними буковими деревостанами уже помітна у 1 класі віку. Тенденції щодо зниження запасів деревини у модальних деревостанах, порівняно $з$ оптимальними, зберігаються до 12 класу віку.

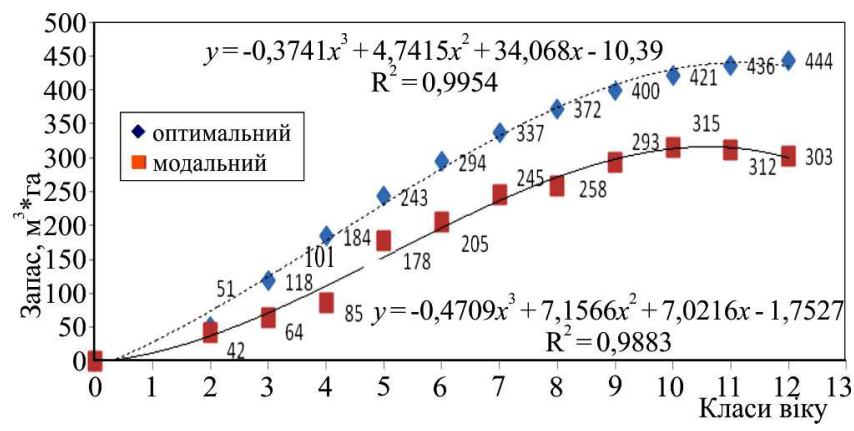

Рис. 4. Динаміка формування середніх запасів оптимальних і модальних (фактичних) деревостанів бука лісового (II бонітет)

При цьому з віком деревостанів відмінності за запасом між оптимальними і модальними буковими деревостанами значно посилюються й у 80-річному віці вони перевищують $100 \mathrm{~m}^{3} \cdot \mathrm{ra}^{-1}$. Отже, серед основних деревних видів Поділля найгірше використання типологічного потенціалу спостерігається порослевими дубовими деревостанами. Встановлено зростання зниження запасу деревини у модальних деревостанів відносно оптимальних зі збільшенням віку. Особливо ці відмінності посилюються з 80-100-річного віку.

У табл. 1 наведено розрахунок загальних втрат деревини від недовикористання під час проведення рубок головного користування. За зведеними даними, середній оптимальний запас для основних деревостанів Поділля становить близько $340 \mathrm{~m}^{3} \cdot \mathrm{ra}^{-1}$. Величина фактичного запасу становить $237 \mathrm{~m}^{3} /$ га. Відхилення середніх запасів деревостанів становить $104 \mathrm{~m}^{3} \cdot \mathrm{ra}^{-1}$ (32\%). Найбільші втрати від недовикористання лісорослинного потенціалу та запровадження неефективних лісогосподарських методів характерне для дубових лісостанів порослевого походження (50,1\%). Значна величина втрат продуктивності властива також буковим (30,3\%) лісостанам. 
Табл. 1. Розрахунок орієнтовних втрат від неповного використання лісорослинного потенціалу основних лісотвірних порід України

\begin{tabular}{|c|c|c|c|c|}
\hline \multirow[b]{2}{*}{ Порода } & \multicolumn{2}{|c|}{ Середній запас, м ${ }^{3} \cdot \mathrm{ra}^{-1}$} & \multirow{2}{*}{$\begin{array}{c}\text { Відхилен- } \\
\text { ня запасів, } \\
\text { м }^{3} \cdot \mathrm{ra}^{-1} \\
\end{array}$} & \multirow{2}{*}{$\begin{array}{c}\text { Втрати } \\
\text { запа- } \\
\text { су, \% } \\
\end{array}$} \\
\hline & оптимальний & фактичний & & \\
\hline $\begin{array}{l}\text { Дуб н } \\
\text { сіннєв }\end{array}$ & 349 & 264 & 85 & 24,4 \\
\hline $\begin{array}{c}\text { Дуб поросле- } \\
\text { вий }\end{array}$ & 267 & 1. & 134 & 50,1 \\
\hline Бук лі & 27 & 19 & 83 & 30,3 \\
\hline Середнє & 340 & 237 & 104 & 32,0 \\
\hline
\end{tabular}

Зведену інформацію щодо втрат продуктивності від усіх факторів наведено в табл. 2. 3 таблиці видно, що основна частка втрат продуктивності деревостанів зумовлена недовикористанням лісорослинного потенціалу (32,04 \%). Втрата від інших факторів є незначною і не перевищує $1 \%$ від загального запасу деревини.

Табл. 2. Зведені результати щодо втрат запасу деревини основних лісотвірних деревних порід України від усієї сукупності факторів впливу

\begin{tabular}{|l|c|c|}
\hline \multicolumn{1}{|c|}{ Фактор втрати продуктивності } & $\begin{array}{c}\text { Загальний за- } \\
\text { пас, млн м }\end{array}$ & $\%$ \\
\hline $\begin{array}{l}\text { Недовикористання лісорослинного по- } \\
\text { тенціалу у віці РГК }\end{array}$ & 576,72 & 32,04 \\
\hline Комахи-шкідники та хвороби лісу & 6,48 & 0,36 \\
\hline Вітровали, сніголами, буревії & 11,52 & 0,64 \\
\hline Лісові пожежі & 22,50 & 1,25 \\
\hline Незаконна заготівля деревини & 0,18 & 0,01 \\
\hline Загальні втрати продуктивності & 400,68 & 34,66 \\
\hline
\end{tabular}

Висновки. Недовикористання лісорослинного потенціалу є одним із основних факторів зниження продуктивності деревостанів. За таких умов втрати становлять близько третини загального запасу деревостанів. Основними чинниками зниження ефективності використання лісорослинного потенціалу є надмірне зрідження середньовікових деревостанів у період їх формування.

\section{Перелік використаних джерел}

Bondar, A. O. (2003). Productivity of partial oak trees in Podillia. $\mathrm{Li}$ sivnycztvo i agrolisomelioraciya, 104, 139-143. [In Ukrainian].

Bondar, A. O., \& Hordiienko, M. I. (2006). Formation of forest plantations in the oaks of Podillya. Kyiv: Urozhai, 325 p. [In Ukrainian].

Didenko, M. M. (2008). The state of the natural renewal of oak is under the parent tree. Lisivnycztvo $i$ ahrolisomelioraciya, 113, 186190. [In Ukrainian].

Holubets, M. A. (2003). Modern problems of forestry and silviculture. Proceedings of the Forestry Academy of Sciences of Ukraine, 2, 20-26. [In Ukrainian].

Levchenko, V. V. (2006). Natural seed propagation in fresh otters of the northern part of the right-bank forest steppe. Candidate Dissertation for Agricultural Sciences (06.03.03 - Silvics and Forestry). Kyiv, 19 p. [In Ukrainian].

Maurer, V. M., Hordiienko, M. I., \& Brovko, F. M. (2008). Theoretical and technological basics of forest reproduction on the basis of ecologically oriented forestry: scientific and methodological recommendations. Kyiv: NUBiB Ukrainy, 63 p. [In Ukrainian].

M. V. Matusiak

Vinnytsia National Agrarian University, Vinnytsia, Ukraine

\section{THE USE OF TYPOLOGICAL POTENTIAL OF MAJOR SCALES IN PODILLYA REGION}

The main purpose of these studies was to determine the forest-typological potential of the main forest species of seed and vegetative origin. In the course of the research, a number of differences were detected between the growth rates and the productivity of seed and sprout plots of the main forest species of Podillya. As a result of our research, we discovered that the difference between the oak stocks of the usual vegetative origin of modal and optimal tree stands is clearly traceable already in the 2nd grade of the age. The largest difference in the stock manifests itself at the age of 100 years and is almost $50 \%$. It is established that in the oak seedlings of seed origin the difference between optimal and modal tree stands is most pronounced at the age of 110 years and continues to grow to 140 years. We also studied the forest-typological potential of seed grasslands. In the course of the research, we determined that a significant decline in the stock of modal ash-tree stands is observed at 80-100 years of age. It is estimated that at 140 years of age, the stock of wood in modal woodlands was $170 \mathrm{~m}^{3} \cdot \mathrm{h}^{-1}$ lower than in the optimal. In beech trees with age, the difference in stock between optimal and modal indicators is significantly increased and at the age of 80 , the difference is $100 \mathrm{~m}^{3} \cdot \mathrm{ha}^{-1}$. According to the collected data, the average optimal reserve for the main stands of Podillya is about $340 \mathrm{~m}^{3} \cdot \mathrm{ha}^{-1}$. The actual stock is $237 \mathrm{~m}^{3} / \mathrm{ha}$. The deviation of the average stock of stands is $104 \mathrm{~m}^{3} \cdot \mathrm{ha}^{-1}(32 \%)$. The greatest losses due to under-utilization of forestry potential and the introduction of ineffective forest management methods are characteristic for oak $(50.1 \%)$ and beech $(30.3 \%)$ woodland. According to the data, we found that the main part of the loss of productivity of the stands was due to the under-utilization of the forestry potential $(32.04 \%)$. Loss from other factors is insignificant and does not exceed $1 \%$ of the total stock of wood.

Keywords: forestry potential; stock; productivity; age; main felling; forestry breeds. 